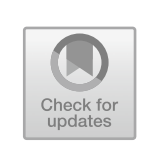

\title{
6
}

\section{Unfolding Crisis and Great Transformation (2013-2020): From Globalization to Ecological Civilization as Localization}

\section{The Crisis of Globalization and the New Cold War}

Entering 2020, China's tenth economic crisis since 1949 broke out in a dramatic conjuncture. Unlike the previous nine crises, this crisis was no longer a cyclical economic crisis in the classical sense. ${ }^{1}$ The cycle of industrial capitalist crises was subverted by the 2008 Wall Street financial crisis. In the ten or twelve years after the crisis, the global economy was still characterized by the classical cyclical crisis of the twentieth century. For example, after the end of QE policy during 2013-2014, China experienced monetary contraction along with overproduction. Out of a status of dependency and structural complementarity, China strove to make use of its overproduction at the expense of environmental and social welfare to complement the US economy, attempting to sustain this unequal relationship. Under such unfavourable conditions, China

\footnotetext{
${ }^{1}$ In classical sense, crisis is caused by overproduction and declining profitability. An economic cycle is expressed as the fluctuation of prices and enterprises life cycle. In financial capitalism, a large part of capital does not flow into real economy. Hyman Minsky supplemented it with the financial cycle through credit creation.
} 
still desperately endeavoured to pursue the path of modernization which has unfolded as globalization in the last 30 years. However, the golden age of globalization might have come to an end.

Early 2020 marked the end of an era both for China and the world. ${ }^{2}$ If the 2008 crisis had been the crisis of financial globalization, then the 2020 crisis was the crisis of globalization itself. In 2020 people was witnessing the historical seismic shift of the global system itself. After a hundred year of reckless pursuit of industrialization and urbanization, China was confronted by the crisis of globalization, in fact the crisis of modernization itself. Nevertheless, many who strongly believed in this path were still dreaming of "back to business as usual". They were conceiving of all sorts of measures attempting to resume normal economic operations. However, blind to the essential shift in global political conditions, one would be almost irrational if still clinging to economic rationality. Borrowing a famous slogan at the beginning of globalization, it may be expressed as "It is politics, stupid!"

\section{Debt Regime and the Heavily Indebted Hegemony}

Another characteristic of the time is debt becoming a new institutional arrangement. It can be seen, entering the twenty-first century, the global debt regime has been turned upside down. Now the most powerful country has become the most heavily indebted nation. It is the debtor country which holds the institutional power and repudiates debts. The powerful debtor has become a shameless repudiator. It may be less surprising if the readers are reminded that modernization is always intrinsically costly. The more modernized an institution, the more costly it is. In the age of financial capitalism, the high costs of ultra-modernized institutions (such as modern government, welfare and democracy) are sustained by mounting debts. The difference between the USA and China rests with the former being indebted to other countries while the latter is indebted internally.

\footnotetext{
2Some may believe that the twentieth century ended at 1991 when the USSR collapsed. Some ideologues even claimed it the end of the history. However, viewed from the reckless pursuit of modernization, the long twentieth century may have ended at 2020.
} 
Now debt has become a new regime with new institutional arrangement. In the past, the heavily indebted countries were requested to transform their institutions, making their people suffer, usually according to neo-liberal tenets. Nowadays, the powerful debtor country in turn requests creditor country to transform its institution to benefit the former. Ironic and ridiculous it may seem, eventually the country which holds the international institutional power and discursive power can twist the principles it once sanctified ${ }^{3}$ in order to maintain its privilege. The developing countries which fell into the debt trap since the 1980s might find it revealing that even if they followed the instructions to transform their institutions, the global debt problem would be not solved. The outrage lies with the powerful debtor country transfering their institutional outward cost through indebtedness while requesting its creditor to change their institutions. Even more ridiculous, the ultramodern institution, which is shored up by increasing indebtedness and barely sustainable, is in turn taken as the example to be emulated by the creditor country. Such is the farce of the times.

The countries which hold the institutional power cling to the old path whereas those countries without institutional power have little reflection and institutional innovation. The whole global regime therefore becomes increasingly degenerate, probably until it implodes.

\section{Recourse to Cold War Strategy}

With the lack of the capacity of innovation in thinking and social institution, the old hegemony which is now heavily indebted is clinging firmly to its obsolete institutional and discursive power. Hence, unsurprisingly it has recourse to the old experience of Cold War victory out of path dependence. As a reactionary response to the challenge of the crisis of globalization, a New War has become increasingly irrational and even strips bare the old mantle of political correctness. It is the hegemony's desperate effort to sustain its privilege to transfer the cost of debt crisis to the world.

${ }^{3}$ The Washington Consensus can be boiled down into two core tenets: free capital flow and absolute creditor right. 


\section{From Delinking to Re-Linking to US-China Decoupling}

During the first two decades of China's participation into globalization, the two continental nations were actually in a state of symbiotic complementarity in term of economic structure, despite constant political disputation. China's rapid industrialization was concomitant and complementary with the USA's deindustrialization and deeper financialization. The key mechanism coupling China with the USA was the great dollar circuit between them. US dollars circulated into China through trade deficits and recycled back to the USA through China stocking up treasury bonds. This great dollar circuit was a particular international institutional arrangement. The post-WWII international trade regime had been shaped and dominated by the USA. China's initial integration into globalization was possible only because the USA granted it the institutional right to take part into the global trade regime after the diplomatic rapprochement in 1979. China was allowed to take a ride on the accelerating train of global trade led by the USA. But it was not a free ride. Indeed the costs have been substantial, considering the ecological cost and labour force China has contributed during these decades, not to mention the astronomical profits US transnational corporations have earned from it and the improvement of the natural environment in the US due to deindustrialization. Viewed in this way, the dollar circuit as an international institutional arrangement was a form of seigniorage. The USA is the only nation on the planet that is able to keep trading what it desires from other countries simply by creating numbers out of nothing on a balance sheet.

As a consequence, China became increasingly dependent on the USA economically and institutionally.

Compared with the last nine major crises since 1949 we have elaborated in previous chapters, the unfolding tenth crisis shared many of the main characteristics but also had its particularity in this specific historical moment.

Similar to the second to fourth crises in the late 1950s to 1960s, China was punished because of its insistence on maintaining its relative independence and sovereignty and not totally submitting to the dominant hegemony. During the 1960 s, China was forced to take the path 
of self-reliance after the interruption of Soviet assistance and sanctions by the West. It thereby achieved "delinking." However, since the early 1970s, China once again brought in foreign capital. And by the late 1990s, China had been integrated into globalization. As a result, China's industry and economy again became dependent on the West.

Nearly fifty years after China began accepting the inflows of western capital and twenty years after its reintegration into the global economy, the USA, while still dominating international institutional power and holding currency hegemony, threatened to punish China through a "trade war". Superficially, the reasons were to do with the huge trade deficit as well as allegations like forced technology transfers and theft of intellectual property as well as trade secrets. In fact, imposing heavy tariff on Chinese products would not improve the trade deficits. It might help little to motivate the reshoring of manufacturing back to the USA. The imbalance of the US economy originated from its structural problems at the advanced stage of financial capitalism. In fact, American enterprises and consumers would not benefit from the trade war. This was demonstrated by its rising trade deficits as well as by various studies. ${ }^{4}$

The Obama and Trump administrations were actually quite consistent in the strategic aims they claimed to be attempting to achieve, namely re-developing the real economy (manufacturing) in the backdrop of the hyper development of financial capitalism. However, it was doubtful that Trump would succeed where Obama had failed. The practical consequence of the trade war was in fact an effort to reshape the global economic structure and to prevent China's attainment of economic optimization and relatively greater independence through its development of technology and its fine-tuning of the international trading structure. Its strategic goal was not different from the Transpacific Partnership (TPP) advocated by Obama administration, which aimed at remaking global trade rules. In either case, China was in fact given two options: greater submission or be excluded from the new global trade regime with the US still at its core. The so-called structural reform the USA requested in

\footnotetext{
${ }^{4}$ See, P. D. Fajgelbaum, P. K. Goldberg, P. J. Kennedy, A. K. Khandelwal, 'The Return to Protectionism'; Trade Partnership Worldwide. LLC, 'Estimated Impact of Tariffs on the US Economy and Worker 2019'; M. Amiti, S.J. Redding, D. Weinstein, 'The Impact of the 2018 Trade War on U.S. Prices and Welfare'.
} 
fact constituted for China greater submission or structural dependency. Meanwhile, no country on this planet is able to impose structural reform on the USA, its structural imbalance of which has become a major source of instability in the global economy. Herein is US exceptionalism. The USA is not just an equal member of the global community. She is the rule maker. The post WWII global trade regime was created by the USA to serve its interests. It is the only country in the world being able to stay prosperous in spite of decades of growing trade deficits.

In reality, those who have benefited most from China's incorporation into the global economy were transnational capital (especially US capital) and Chinese capitalist elites. All this occurred at the great expense of ecological degeneration and the extraction of surplus value from labour. Nonetheless, China did demonstrate substantial development. However, its industry was still highly dependent on the advanced countries. Transnational corporations took the largest share of the added value created in China. In the financial sector China still insisted on its sovereignty, which induced discontent from foreign financial capital hoping to seek higher profitability in China.

The dependent status of China in the two decades of integration into globalization could be partly reflected by its incomplete currency sovereignty. As stated above, for a long period China's money base mechanism was exogenous and dependent on its foreign exchange stock as it is accumulating a huge amount of foreign exchange reserve mainly consisted by US dollar. Therefore, China's monetary policy was susceptible to the Federal Reserve's policy and US monetary strategy and ineffective in regulating the domestic economy.

\section{From Structural Complementarity to Institutional Delinking}

China's inferior status in the global trade regime could also be reflected in its lack of rights in the pricing of major commodities. Despite being the largest importer, China lacked the right to negotiate the price-setting of major commodities as the major settlement currency is the US dollar and the international commodity markets are highly speculative. In recent 
years, China has been establishing its own commodity markets to gain bigger pricing power. One effort was the emergence of the Petro RMB, which was naturally regarded by the USA as a threat to the petro dollar, the cornerstone of US national interests since the 1970s. In other words, China was endeavouring to set up a preferable international trade regime, if the existing regime could not be fine-adjusted to more favourable conditions.

Of course, inside China there were two strategic stances concerned with how China should relate with the USA. One line claimed that it was actually more beneficial to China continuing and even deepening its submission to the USA. However, the problem was how the USA could avoid the mentality of the Thucydides Trap as it had successfully put a curb on Japan and later Europe, not to mention its much praised victory over the USSR.

Another line of thought believed that lesser dependency on the USA was vital to the further development of China. Made in China 2025 strategy represented the country's effort to develop core advanced technologies as a way to shake off the status of industrial dependency. It was not a coincidence that US elites decided to launch a trade war against China at this particular historical moment.

\section{Economic Iron Curtain: From TPP to Economic Prosperity Network or Other Future Initiatives}

The 2008 global financial crisis marked the end of the golden age of globalization. Since then both the USA and China were pushing strategic transformation in economic structure as a response to crisis. The consequence was a seismic shift of the strategic relationship between the two great powers. As early as in 2015, while terms like "Chimerica" and "G2" were still sort of fads in academia and media, we had proposed the imminent US-China Decoupling.

The strong rhetoric and idiosyncrasies of the Donald Trump Administration might make people forget that the US trade war against China actually had its origin in the Trans-pacific Partnership pushed by Obama administration. After the 2008 financial crisis, US government had 
consolidated its strategy of transferring its cost of financial crisis to other countries, including emerging countries such as China. At the same time the Obama administration also launched the high-key Rebalance Strategy and pushed the exclusive TPP initiative. Despite disparity in strategic style, American leaders were in fact highly consistent in the attempt to exclude China from the global regime in which the USA still played a dominant role. Whether it was the aborted TPP or the trade war against China in 2018 launched by the Trump administration and the latterly proposed Economic Prosperity Network, the strategic aims were in fact quite consistent, namely firstly attempting to put a curb on China's effort to shake off dependence and secondly punishing by exclusion if China refused to yield to the yoke in greater submission; nevertheless, it was dressed up by the New Cold War ideology as China taking a free ride of globalization but without embracing western democracy.

The Chinese leadership proposed in 2012 a "New mode of Major Power Relationship" as an attempt to define the US-China relationship based on common interests and despite divergence. However, it turned out to be wishful as the Obama-Hillary Clinton Adminstration instead pushed forth the Rebalance strategy to contain China in the region. In December 2017 the National Security Strategy of the United States redefined China from a "stakeholder" as one of the revisionist powers, which challenged the US-led world order. In other words, in spite of China's wishful vision of strategic partnership, the USA now regards its counterpart as a major strategic competitor and even potential threat of hot war not unlike countries like Iraq and Iran. On March 22 2018, the US Presidential Memorandum blew the bugle calls of the Trade War.

A systematic strategic containment of China became the consensus of US top political elites. It was not a result out of the spontaneity of an idiosyncratic leader, nor the preference of a single party. 


\section{Reverse-Globalization or the Exclusion of China from the Global Trade Regime}

The 2008 crisis had been a crisis of the financial globalization. The globalization regime kept working for ten more years but failed to fully recover until this full-scale crisis of globalization as a whole. After globalization had exhausted its first phase resulting in widening wealth disparity around the world, some populist demagogues adopted a sort of anti-globalization discourse as a way to please their constituencies. However, upon a closer look at their policies, we found little evidence of practices of deglobalization ${ }^{5}$ although there would be a trend of reshoring in certain key strategic sectors. ${ }^{6}$ The present trend was more a reconfiguration than the disintegration of globalization. The result might be just an altered form of globalization at a lesser scale but no less intrinsically pro-capital and pro-elite. What was unfolding may be regarded as reverse-globalization. Or it might be called global regionalization.

In retrospect, China was admitted into the global trade regime in 1972 led by the USA because of the latter's half a century long rivalry with a chief opponent, the USSR. The first phase of the globalization started at the end of the Cold War. The so-called victory in a political and ideological war over a major enemy had granted the USA with the confidence to open its global trade regime to any country willing to play the game. At this phase, the globalization regime was a gigantic profit machine based on highly complicated global supply chains and extraction of cheap production factors, such as labour, land and resources.

\footnotetext{
It depends on how one defines globalization. We think that during its prime time in the last three decades, the unit of globalization has always been nation-state. Certainly, globalization is characterized by the permeability of state by capital. But the erosion of state power is only relevant to countries in a less privileged position in the global regime. For the powerful core countries, it is not the case. Therefore, a revival of nationalism in political discourse does not necessarily imply genuine de-globalization in practice. For us, a genuine de-globalization should be pro-people's wellbeing and empowerment, not to mention pro-ecological regeneration. However, many of the populist demagogues are in reality highly elitist and pro-capital.

${ }^{6}$ Reshoring was not a strategy limited to the USA. Japanese government also planned to offer subsidies up to $\$ 2.25$ billion to Japanese companies bringing supply chain back home.
} 
Nevertheless, the second phase of globalization (or post globalization era if one likes it) would be more about alliance of ideological and geopolitical compatibility than merely profit-making. In a sense, it was an endeavour to retrograde to 2001 before China joined WTO, or even to 1972 before China had rapprochement with the USA.

\section{Global Regionalization}

So far, what we have witnessed at the beginning of the post-globalization era is the formation of global regionalization, which may be an alter form of globalization. The NAFTA has been reshaped into the United States-Mexico-Canada Agreement (USMCA). Launching a New Cold World, the USA is mobilizing like-minded countries to form an antiChina geopolitical and trade alliance. In fact, apart from the trading regime, the US under Trump Administration is attempting to decompose and reconfigure almost all international institutions with only one principle: to form an anti-China alliance. The Anglophone Five Eyes Alliance members have often also been the ex officio core members of most of US geopolitical initiatives. India, regarding itself as the regional competitor of China, would be also keen at joining any US initiative aiming at containing China and see themselves as possibly benefiting from the ripping of Chinese supply chain.

The European Union, after continuous shocks of PIIGS Sovereignty Debt crisis, Brixit and COVID-19, is struggling to regain its footing to rebuild the solidarity of Europe. To help fiscally less favourable members to recover from the blow of COVID-19, Germany and France proposed $\mathrm{a} € 500$ billion Recovery Fund providing grants to European countries in need. The European Commission would raise money by borrowing on the markets, which would be repaid from the EU budget. Most importantly Germany has changed her firm position of rejecting debts-sharing. It might mark an important step toward the fiscal unification of the EU. It is well known that the design of Euro was defective in the deficiency of fiscal unity among EU members. Fiscal unification might strengthen Euro's presence in the global financial system. EU bonds would be an alternative to the US Treasury Bonds. Then Europe might become an equivalent strategic competitor to the USA. 
Undoubtedly, the EU would continue to play an important role in the world. However, caught in the confrontations between the USA and China, as well as the USA and Russia, it would have to seek a balance between these powers. Lack of a united administration and without its own independent arm force, the EU would find it not competent enough to deal with the overspill of conflicts in some of the turbulent regions proximal to Europe.

In Asia, the regional integration of China, Japan, Korea and ASEAN appears to be the most beneficial direction for all countries in the region. However, Japan and Korea, lacking complete military autonomy, would have to struggle in the dilemma of whether to befriend a nonnegligible neighbour with which it has close economic ties or yield to their de facto military suzerain. ASEAN countries, likewise, have close economic connection with China. However, the region has been plagued by complications arising from the South China Sea dispute, which has been proactively inflamed by the interventions of external powers.

Entering the twenty-first century, China appeared to have the greatest international presence since the late nineteenth century. However, after forty years of relatively peaceful times and having waived its competitiveness in institutional and discursive power, China suddenly finds itself in an increasingly hostile geo-political surrounding. At the international level, decades of China-bashing in international media precipitated into blatant demonization after the COVID-19 outbreak in 2020. The third decade of the twenty-first century would not be an easy era for Chinese diplomacy.

\section{Fast Track to a New Cold War}

An epidemic by an unknown coronavirus later dubbed as COVID19 broke out in China. After having confirmed its contagiousness and fatality, Chinese government responded swiftly in the January of 2020 with decisive measures including locking down Hubei provinces, the epicentre of the epidemic and halting all non-essential economic activities nation-wide. The central government mobilized the whole nation's power to take on an unforeseen challenge. These measures and efforts 
proved to be effective in containing COVID-19. ${ }^{7}$ The outbreak and its containment in China also showed that a functional and wellcoordinated administration is invaluable to any nation. China's administrative effectiveness has been an institutional legacy since the revolution era, despite much demonization and criticism by the West. ${ }^{8}$ In some western countries, the official and mainstream epidemic discourse implied an innuendo of social Darwinism whereas personal freedom was hailed as prior to collective interests and the poor, the aged, the coloured and the underprivileged were the most seriously impacted social group, economically and pathologically. While many countries were still paralyzed by this century epidemic, China was among the first to resume normal daily life and economic activities. However, the US government failed to contain the epidemic while the leadership took a scapegoating approach and blamed China for spreading the coronavirus, despite international medical professionals generally speaking highly of China's efforts in containing the epidemic.

After the trade war and COVID-19 outbreak in 2020, the SinoAmerican relationship fell to its worst moment since 1989 and showed no sign of relief. The 1990s was the time when globalization was rising and international capital was seeking after cheap production factors. Therefore the 1989 sanction lasted only for a few years. Soon after that China was re-admitted and fully integrated into globalization. Nevertheless, after three decades the situation has become different. Now globalization has come to the bottle neck. And most importantly, three decades after the Cold War, China emerged from being the second to the major opponent of the USA. In a sense, the US-China relationship has retrogressed to the situation prevailing before 1972. Just that China

\footnotetext{
7"The outbreak containment strategies in China based on non-pharmaceutical interventions (NPIs) appear to be effective...Without NPIs, the COVID-19 cases would likely have shown a 67-fold increase (interquartile range 44-94) by February 29, 2020..." in S. Lai, N.W. Ruktanonchai et al. "Effect of non-pharmaceutical interventions to contain COVID-19 in China," Nature, 4 May 2020. https://www.nature.com/articles/s41586-020-2293-x. Also: "An investigation of transmission control measures during the first 50 days of the COVID-19 epidemic in China," Science, 8 May 2020.

${ }^{8}$ About the US administration's poor performance in handling the outbreak, read Joseph E. Stiglitz, "Plague by Trumpism" March 9, 2020, Project Syndicate. https://www.project-syndicate. $\mathrm{org} /$ commentary/trump-coronavirus-failure-of-small-government-by-joseph-e-stiglitz-2020-03.
} 
now took the place of the USSR as the prime enemy of the USA. As a Newsweek essay put it, "Thus, a growing number of policymakers, current and former, and China hands old and new, acknowledge the obvious: Cold War 2.0 is here." 9 And Joseph Bosco, a former Pentagon strategic planner and vociferous Anti-China hawk, expressed it in an unmistakably Cold War language: "Another long twilight struggle may be upon us and it may make the last one look easy" (ibid.).

In US strategic conception, its competition with China was full scale and in all major fields: Economy (extending to finance and currency), Military Superiority (extending to the space), Geopolitics, Technology, National Security, International Institutions and Ideology. ${ }^{10}$

As for the economy, what was taking shape would constitute a seismic shift splitting the global trade regime that would shake the world order. Be it passively or proactively, to save its survival in the global industrial chain, China had to establish an alter-international trade system, splitting from the old regime currently which was reshaping itself, with the USA still as the core. The problem was that the USA increasingly took to adopting a New Cold War approach. In its official discourse ${ }^{11}$ and high ranking officers' speeches, the USA's engagement with China was raised to the level of an antagonistic rivalry between two opposite ideologies and even civilizations. Worse still, the USA was obsessed with forcing other countries, enterprises and international institutions to take sides

\footnotetext{
${ }_{9}$ Bill Powell, "America Is in a New Cold War and This Time the Communists Might Win" 1805-2020, https://www.newsweek.com/2020/06/05/america-new-cold-war-this-time-communistsmight-win-1504447.html.

${ }^{10}$ US Congressman Michael McCaul, Republican Leader on the House Foreign Affairs Committee, announced on 19 May 2020 the pillars of the China Task Force: National Security, Technology, Economics and Energy, Competitiveness, and Ideological Competition. He said, "Each of these pillars represents a key focus area where U.S. leadership and democratic values counteract Chinese Communist Party (CCP) malfeasance globally. The five pillars reflect the key aspects of our strategic competition with China, as identified by our members: military superiority and homeland security; advanced technology; economic strength; increasing our competitiveness; and the battle between democracy and authoritarianism. We must take decisive action across each of these vital domains to better secure our future." https://gop-foreignaffairs.house.gov/press-release/ mccaul-announces-china-task-force-pillars-and-co-chairs/.

${ }^{11}$ See: U.S. Strategic Approach to the People's Republic of China. This report by the White House articulated its whole-of-government approach to China under the 2017 National Security Strategy. https://www.whitehouse.gov/wp-content/uploads/2020/05/U.S.-Strategic-App roach-to-The-Peoples-Republic-of-China-Report-5.20.20.pdf.
} 
by measures such as poison pill provisions, supply chain blockades and sanctions.

It might be too early to call whether the new cold war would lead to full scale military confrontation. If it is a soft delinking, what we would witness might be the emergence of two economic cores with overlapping supply chains and markets to some extent. For a certain period, the two cores would still be interwoven in a complicated manner. However, if the confrontation escalates and eventually leads to a hard decoupling, then the probability of regional military tension and even proxy war cannot be not excluded. Bill Powell put the US new mission concisely: "Wage the 21 st century's Cold War, while ensuring it never turns hot" (ibid.). However, the historical lessons of the World Wars I \& II show us clearly that any attempt of playing a rival game to gain greater supremacy while believing one could avoid full scale military confrontation is an illusion.

During this great splitting of the most important relationship in the world, what is truly worrying is less about the so-called Thucydides Trap. The mentality of the an alpha nation not tolerating the rise of a potential competitor might not necessarily result in a disastrous clash. It is the unsustainability of the present debt regime that should bother us. The old financial regime with the Federal Reserve mechanism as the core has increasingly become similar to a Ponzi scheme. Many major central banks in the world had reverted to quasi-quantitative easing of various sorts because there was not enough private demand to keep the game going. If China refuses to continue playing the role of paying tribute to the suzerain as it has in the last 20 or 30 years after the decoupling, would the world find a contributor big enough to sustain the game? If the big game of debt is no longer sustainable like the situation before the WWII, does it imply a new world war looming on the horizon?

The two nations are heading towards strategic collision in this post globalization era. This great shift may bring forth an even more complicated scenario in a world plagued by debt, recession, unemployment, widening wealth disparity, social turmoil, political conflicts and ecological catastrophe. 


\section{Post-epidemic Impact: Towards a Hard Delinking}

After months of intense dispute, China and the USA reached an agreement in January 2020 aiming at easing the trade war stage by stage. According to the deal, China had to commit to increasing imports from the USA by at least US $\$ 200$ billion above 2017 levels and strengthening intellectual property protection. Other terms included opening up market access for financial service and easing legal action over so-called "trade secret theft". The scale of the purchase promise was so large that people generally regarded China had made major concession to the USA allowing both sides a way out of the scenario of full-scale confrontation.

However, no matter how much Chinese government was willing to concede with promises to balance trade and open up financial and capital markets, the US ruling elites did not appear to be not easily appeased. A tentative trade agreement with China did not stop the US government from further ripping global supply chains from China, including banning leading Chinese IT enterprises from getting advanced technologies related with US companies. This amounted to a technology blockade.

\section{Box 1: US Technology Blockade}

On May 15 2020, US Bureau of Industry and Security announced plans to restrict the leading Chinese IT enterprise Huawei from making use of U.S. technology and software to design and manufacture its semiconductors on the ground that it was "engaged in activities that are contrary to U.S. national security or foreign policy interests".

However, beneath the pretext of national security, the genuine reason of the technology blockade against China was expressed unabashedly by William Barr, US Attorney General, in a public speech:

It is the pivotal nature of $5 \mathrm{G}$ technology and the threat arising from the Chinese drive to dominate this field. 5G technology lies at the center of the technological and industrial world that is taking shape. In essence, communications networks are not just for communications anymore. They are evolving into the central nervous system of the next generation of internet, called the "Industrial 
Internet," and the next generation of industrial systems that will depend on that infrastructure. China has built up a lead in 5G, capturing 40 percent of the global $5 \mathrm{G}$ infrastructure market. For the first time in history, the United States is not leading the next technology era [bold added]. ${ }^{1}$

It was out of this anxiety of being surpassed in technological competition for the first time in more than a hundred years that the US was determined to contain China's technological advancement by all means. ${ }^{2}$

In fact, it was not the first time the USA applied non-market means in an attempt to defeat potential competitors, even US allies. In the 1980s, the rise of Japanese enterprises in the semi-conductors market had threatened the USA's bellwether status. In 1985, Japan surpassed the US to become the largest semi-conductors producer in the world. In 1989 , Japan held $53 \%$ of the world market whereas the US merely $37 \%$. On the pretext of national security threat, the US government started to make use of various means to suppress Japan's lead in the field. By a series of US-Japan Semiconductors Agreements since 1986, along with the Plaza Accord in 1985, the US succeeded in gradually strangling Japanese semi-conductor industry. By the 2010s, Japan had basically lost its share in the global chip market.

Of course, the US selective technology blockade against China was a gamble. In 2018, China imported US $\$ 312.1$ billion of integrated circuit products, comprising two third of the global trade volume of semiconductors, with a trade deficits of more than US $\$ 200$ bn. The blockade might in turn hurt US enterprises and eventually undermine its lead in the industry. A report by Boston Consulting Group, How Restrictions to Trade with China Could End US Leadership in Semiconductors, ${ }^{3}$ expressed this concern. If the Chinese semiconductor industry could survive, China might achieve delinking from its technological dependence on the USA. However, out of strategic path dependency, the US considers it imperative to knock out any potential competitor, especially when it is not considered an ally but instead a strategic competitor.

References:

1. https://www.justice.gov/opa/speech/attorney-general-william-p-barrdelivers-keynote-address-department-justices-china.

2. The Wassenaar Arrangement on Export Controls for Conventional Arms and Dual-use Goods and Technology also affords the US with the 
power to put pressure on the signatories in exporting goods and technology which the US considered may be used for military application and contrary to US interests.

3. https://media-publications.bcg.com/flash/2020-03-07-How-Restricti ons-to-Trade-with-China-Could-End-US-Semiconductor-Leadership. pdf.

Furthermore, the US government planned to attach a "poison pill" provision in all trade agreements with trade partners, which endowed the USA with the veto over its partners making trade agreement with so-called "non-market country" it defined. The provision was widely regarded as specifically anti-China.

From the standpoints of transnational corporations which had benefitted most from globalization, the reconfiguration of global trade regime or reshoring to the USA in fact harmed their short-term profits. ${ }^{12}$ However, what the US political elites were concerned with was the longterm national strategies. For this major strategic adjustment, the US enterprises were requested to endure the shock of global reconfiguration of the trade regime.

The COVID-19 global outbreak staged another episode of the ongoing saga with further dramatic conflicts. The epidemic terminated the 128 month boom, the longest record in US history since $1854 .^{13}$

\footnotetext{
12Thomas J. Donohue', CEO of the U.S. Chamber of Commerce, warned on April 2020 that ripping US supply chain out of China by over reshoring could harm the US economy. https://www.reuters.com/article/us-health-coronavirus-supply-chains/bus iness-group-cautions-u-s-on-reshoring-too-much-china-supply-idUSKBN22V2VO. Bill Powell reported, "In the U.S., a lot of companies simply do not want to reduce their exposure to China. They spent years-and billions-building up supply lines and are loath to give them up. Consider the semiconductor industry, a critical area in which the U.S. is still technologically more advanced than China. A complete cessation of semiconductor sales to China would mean U.S. firms lose about 18 percent of their global market share-and an estimated 37 percent of overall revenues. That in turn would likely force reductions in research and development. The U.S. spent $\$ 312$ billion on R\&D over the last decade, more than double the amount spent by its foreign competitors-and it's that R\&D which allows them to stay ahead of competitors" (Newsweek, 18-5-2020). https://www.newsweek.com/2020/06/05/america-newcold-war-this-time-communists-might-win-1504447.html.

${ }^{13}$ National Bureau of Economic Research Business Cycle Dating Committee. https://www.nber. org/cycles/june2020.html.
} 
And the US economy plunged into recession. Under much criticism in mishandling the crisis with a death toll of over 120,000 (as of June) and the worst economic conditions since the Great Depression, ${ }^{14}$ the US leaders sought recourse to a strategy of scapegoating China, as it was the first country known to discover the outbreak. Xenophobia, racism and conspiracy theory was orchestrated with a distorted form of epidemiology despite disapproval by scientists. ${ }^{15}$ Amidst the outbreak and the US leaders demonizing China, a survey by the Pew Research Center showed that $66 \%$ of the Americans had an unfavourable view of China, the most negative rating since the Center began similar survey in 2005. ${ }^{16}$

We should not forget that the rise of conservative populism was an aftermath of unfettered globalization. Globalization was a process of captialization of resources (or the commons) followed by the virtualization of capital. Financial globalization made it worse as financial capital was in essence exclusive. Therefore, financial capitalism is not about free markets in general sense. It is an exclusive development in which a small group of people takes control of increasingly large amounts of capital. The consequence of financial capitalism is inevitably the widening gap between the rich and the poor, the have-all and the have-nots. It was not an accident that the development of hyper financial capitalism in the 1920 s resulted in the rise of fascism while in the 2000s, it led right wing populism. Populism is in fact an irrational reaction to this widening gap by the lower and middle class.

\footnotetext{
${ }^{14}$ The US unemployment rate was $14.7 \%$ in April. As of 9 May, the number of unemployment was 36.5 million. The Federal Reserve Bank of Chicago indicated that the real unemployment rate might be as high as $30.7 \%$. Low income households were hit hard. A Federal Reserve survey showed that $39 \%$ of low income Americans (with annual income below \$40,000) lost their jobs over the period (compared with $13 \%$ of households with income over $\$ 10,000$ ). Over 100,000 enterprises were closed permanently due to the epidemic. $42 \%$ of work opportunity might be lost permanently. US industrial production in April decreased by $11.2 \%$, the worst in 101 years. The Federal Reserve Bank of Atlanta predicted the Q2 GDP might be contracted by $42.8 \%$. The homeless population might increase by $45 \%$ at the end of 2020 .

${ }^{15}$ See "Stop the coronavirus stigma now," Nature, 7 April 2020. Also Richard Horton, the editor-in-chief of The Lancet pointed out it was unfair to blame China for the COVID-19 pandemic in an interview with Chinese state media. See South China Morning Post, 2 May, 2020.

${ }^{16}$ K. Devlin, L. Silver \& C. Huang "U.S. Views of China Increasingly Negative Amid Coronavirus Outbreak". https://www.pewresearch.org/global/2020/04/21/u-s-views-of-china-increasin gly-negative-amid-coronavirus-outbreak/.
} 
Faced with uncertainty, many US companies planned to adjust their supply chains and lessen their dependency on China. As an economist in the Federal Reserve Bank of New York's Research and Statistics Group stated that, "[g]oing forward, COVID-19 is likely to give further impetus to trends that already began in previous years [due to the trade war]. It is likely to lead firms to consider bringing some critical activities back to the United States or to set up backup suppliers to reduce the firms' exposure to any single supplier or country. While introducing such additional safeguards is going to reduce the efficiency of supply chains in normal times, it may well improve performance in the longer run by mitigating the high costs of supply chain disruptions." 17

The technology blockade and the not totally unlikely possibility of a financial war has alarmed China of its over dependency on foreign core technologies. The government has set its goal of increasing chip selfsufficiency from the current 25 to $75 \%$ in five years. In the Fourteenth Five-year Plan, the state has proposed the principle of independent scientific research capacity and technological self-sufficiency as the foundation of the nation. The aim is to build a Digital China with its own independent IC-chip, 5G, new energies technologies and new material science. The central government has called for an overhaul in education(talent), scientific regime(know-how), economic system (with a coordination of capital, industry and market) and administration. Whether this great expectation may be successful or not would be one of the global focuses determining the course of history in the next 15 years.

People generally believed the China-US relationship would never be the same after the COVID-19 epidemic. It appeared that the bifurcation in scenario would lie at whether the delinking would take place in a smooth and orderly manner or abruptly by some black swan or grey rhinoceros event.

\footnotetext{
${ }^{17}$ Sebastian Heise, "How Did China's COVID-19 Shutdown Affect U.S. Supply Chains?," Federal Reserve Bank of New York, 12 May 2020. https://libertystreeteconomics.newyorkfed. org/2020/05/how-did-chinas-covid-19-shutdown-affect-us-supply-chains.html.
} 


\section{The Formation of an Exclusive Global Financial Regime}

As finance lies at the heart of globalization, the strategic exclusion of China naturally extended to the US-led international financial regime. Global dollar liquidity regulation has been one of the fundamental mechanisms of this regime. Every time when there was a financial crisis, global dollar liquidity would be in a state of contraction. However, because of the lack of alternative source of international credit, the global contraction of dollar liquidity would in turn strengthen the status of dollar as the global currency. The expansion of the currency swap agreement between the US Federal Reserve with foreign central banks beyond the core became an important strategy toward the exclusion of China from the global financial regime.

\section{Box 2: Currency Swap Agreement}

On 31 October 2013, the U.S. Federal Reserve, the European Central Bank, the central banks of United Kingdom, Japan Canada and Switzerland had come to a long-term currency swap agreement to replace temporary mutual liquidity swap agreements. Given the situation of contracting U.S. dollar liquidity, the monopoly system of the six central banks will dominate the polarization of the global monetary, financial and economic system. Monetary and financial markets that entered that system would have liquidity support as well as a 'crisis bottom line premium' assessed by international capital. Economic systems worldwide that did not have the good fortune of sharing that network would be vulnerable to attacks in currency exchange rates and in the financial markets. ${ }^{1}$

Due to the outbreak of COVID-19, the U.S. stock market crash prompted the Federal Reserve take on a new round of Quantitative Easing (QE), which started with USD 700 billion on 15 March 2020, then announced "an open-ended commitment to keep buying assets under its quantitative easing measures." 2 On March 19, 2020, the Federal Reserve announced the establishment of temporary U.S. dollar liquidity arrangements (swap lines) with nine more central banks. "These 
new facilities will support the provision of U.S. dollar liquidity in amounts up to $\$ 60$ billion each for the Reserve Bank of Australia, the Banco Central do Brazil, the Bank of Korea, the Banco de Mexico, the Monetary Authority of Singapore, and the Sveriges Riksbank (Sweden) and $\$ 30$ billion each for the Danmarks National Bank (Denmark), the Norges Bank (Norway), and the Reserve Bank of New Zealand. These U.S. dollar liquidity arrangements will be in place for at least six months." 3

In this way, the monetary system of the West in the financial globalization era is forming a layout similar to that revealed in Immanuel Wallerstein's world system theory, "core - semi-periphery - periphery": the U.S. dollar remains in the central position, and together with the currencies that orbit around it, the Euro, British Pound, the Yen, the Canadian dollar and Swiss Franc, formed the core monetary system. Other economic systems that are of compatible ideologies can make relatively large-scale currency swaps with the six central banks and as such have the nature of a secondary center. The nine newly joined central banks become semi-peripheral. Those economic systems that are excluded from making swaps with the core central banks have the peripheral position.

Sit Tsui

References

1. Xu Yisheng, "From 'Jamaican System' entering into 'New Atlantic System”, China Business News, 3 December 2013.

2. https://www.cnbc.com/2020/03/15/federal-reserve-cuts-rates-to-zeroand-launches-massive-700-billion-quantitative-easing-program.html; https://www.cnbc.com/2020/03/23/fed-announces-a-slew-of-newprograms-to-help-markets-including-open-ended-asset-purchases. html.

3. https://www.federalreserve.gov/newsevents/pressreleases/monetary2 0200319b.htm.

The liquidity swap agreement should have been an important international arrangement to stabilize the global financial system. However, the exclusion of the second largest economy in the world made the motivation of the agreement dubious. The arrangement would function to stabilize the core nations of the global financial regime. Countries at 
the semi-periphery might also benefit from this at the price of their economies being further dollarized and dependent on the dollar regime. Other economies not included into this arrangement had to face greater risk of financial instability as the global economy became increasingly unstable.

\section{A Brief Recapitulation of Major Domestic Economic Aspects During 2013-2020}

This round of crisis actually had its root as early as in 2013 when the US Federal Reserve ended the Quantitative Easing III. Most of the emerging countries were seriously impacted. Even though still ranking among the top in the world, the speed of China's economic growth was slowing down consecutively since 2013, a drop by nearly half from the peak, a situation unprecedented in 20 years. In the official discourse, it was described as the "New Norm". In other words, the old model of globalization into which China had integrated itself exhausted its momentum and the negative externalities accumulated in three decades were biting deep into the society, economy and ecology.

This prolonged economic downturn was an extension of the previous 2008 crisis in the USA. The weak global demand since 2012 had thrown China into deflation. The termination of the US Federal Reserve's QE policy in 2013 had great impact on emerging economies around the world. China was not an exception, though the impact of the Fed's QE policy on it is less serious thanks to its capital controls and more solid economic base. In response to the crisis, the government engaged in "supply side reform" and took measures which were basically "procyclical": going along with rather than against the trend. That meant while the economy was going down, the government took contractionary instead of expansionary measures, unlike the counter-cyclical (expansionary) measures in the cases of 1997 and 2008 to save the economy from further crumbling. For example, during the worrying trend of 'deindustrialization,' the government took to forcibly cutting 
excessive industrial production capacity. However, while the industry was contracting, the financial sector was expanding fast. Driven by the enthusiasm for radical financial reform as advocated by the rising financial interest bloc against the backdrop of declining manufacturing industrial profitability, the frenzy of rapid financialization led to the stock market crash of $2015,{ }^{18}$ followed by the foreign exchange reform which resulted in pressure placed on RMB's exchange rate. The government had to put as much as a trillion US dollar of its foreign exchange reserve in the market to stabilize the exchange rate of RMB.

We may give a quick sketch of Chinese economy in six major aspects which would continue to be of importance in the coming future.

\section{Rapid Financialization Crowding Out Industrial Development}

The most prominent feature of the situation during 2013-2018 was the trend of financialization of the economy crowding out industrial development. China's money supply mechanism in the last 20 years relied heavily on the inflow of foreign exchange reserves. By regulation, all foreign exchange flowing into China was obliged to be sold to the central bank, accordingly expanding the money base. Therefore, enormous trade surplus was rendered into rapid expansion of the money base (M0) from RMB 3 trillion in 2008 to more than 8 trillion at 2018 while M2 from 40 trillion in 2007 to 182 trillion at December 2018. As a consequence, liquidity increased without a corresponding growth in the real economy. During this period, the expansion rate of M2 was almost twice the GDP growth rate. Furthermore the defects in monetary conductive mechanism in banking sector made it difficult for small and medium enterprises in the real economy to obtain credit from banks. Faced with declining profitability in manufacturing and the real economy, capital was driven into the speculative sectors such as the stock and real estate markets. As a consequence, China experienced great fluctuations in the stock markets

\footnotetext{
${ }^{18}$ It was estimated that the government had totally spent RMB 2-3 trillion to save the markets from further crumbling.
} 
during 2013-2018. ${ }^{19}$ After the stock market crumbled in 2015, hot money flowed into real estate sector to create a big asset bubble. This financial crisis was essentially the institutional cost of China being incorporated into global financialization under the pressure of excess financial capital.

The drive towards financialization in China was both endogenous and exogenous. One the one hand, the profitability of general manufacturing was declining due to overcapacity and weak global demand. After the Wall Street financial crisis in 2008 and the subsequent crises in the West, global demand crumbled and diminished the profitability of manufacturing. Although China became the largest manufacturing country in the world, most of its products still generated relatively low added value. Now with its industries being yet to upgrade itself technologically with higher added value, China was threatened by deindustrialization.

On the other hand, China was increasingly participating in financial globalization. After the crisis of 1993, the Chinese banking sector became commercialized along the lines of the Anglo-Saxon model. As a policy to emerge from the 1927 crisis, the Glass Steagall Act (1933) ensured that the functions of commercial banks were strictly separated from investment banking in the USA. This held sway until the Act was repealed in 1999 by the so-called Financial Services Modernization Act. In China, however, the new-born commercial banks in the 1990s dived head-on into the brave new world of high finance capitalism. After two decades of development, China's financial sector has become one of the biggest interest blocs, ${ }^{20}$ increasingly intermingled with the global financial capitalism.

Consequently, the financial sector increasingly became alienated from the real economy. This had two obvious consequences. Whereas small and medium enterprises as well as manufacturing sector found it hard to get credit from banks whose preference was to give infrastructure

\footnotetext{
${ }^{19}$ At its peak at June 2015 , the total value of Chinese stock markets amounted to US\$ 10 trillion, second only to US stock markets.

${ }^{20}$ At its peak, the US financial sector was weighted about $7.6 \%$ of US GDP. However, China's counterpart recorded $8.4 \%$ of the GDP in 2016. The total assets value of Chinese financial institutions ranked as number one in the world.
} 
building, state-owned enterprises, real estate or loan with land or property as collateral, a handful of China's financial giants sucked most of the national economic returns. ${ }^{21}$ The real economy was in turn crowded out by the imperatives of finance. As the real economy hollowed out, the financial interest bloc was pushing for further radical financial reforms, drawing excess liquidity into speculative sectors and creating asset bubbles and expanding debts.

China's financial system at its present mode is not supportive of manufacturing and the real economy. Its stock markets failed to fulfill its supposed function, namely to effectively channel excessive liquidity into the real economy to promote industrial upgrading. After the 2015 crash, hot money seeking profitability left stock markets and rushed into other speculative sectors, the most prominent being real estate. And real estate prices in major cities have sky-rocketed beyond the affordability of most people. To compound the problem, local governments developed a dependence on land and real estate as sources of fiscal revenues.

The stock market crash of 2015 did not halt the financial frenzy. Financial products and derivatives have continued to grow exponentially. As estimated, the value of total assets managed by various financial institutions in 2018 amounts to more than RMB 100 trillion. With a weak economy and declining profitability in the real economy, it is reasonable to be worried with the exponential growth of financial investment and the scenario of Ponzi scheme. The rapid financialization of the last decade has reshaped Chinese economy increasingly to share the traits of a casino economy.

\section{Nonfinancial Enterprises Financialized and E-Finance Bubble}

Moreover, financial investment and real estate speculation become important sources of revenues for many nonfinancial enterprises. Some

\footnotetext{
${ }^{21}$ Eight of the top ten listed companies were banks. And the top four were all state-owned banks. In 2017, the banking sector swallowed half of the total returns of listed companies in Chinese stock markets. The total profits of banks, real estate, securities and insurance companies (the FIRE sectors as dubbed by Michael Hudson, about 300 in number) amounted to $70.3 \%$ of the stock markets while the other 3200 listed companies have to share the remaining $30 \%$.
} 
researchers estimate that in the last ten years, $40 \%$ of the fund raised in stock market has gone to the purchase of financial assets, real estate speculation and all sorts of financial investments.

Hot money also found its way into e-finance along with the rapid development of internet. Since its birth in 2011, the total transaction volume of e-finance has grown over RMB 17.8 trillion. In July 2018, many Peer to Peer financial platforms closed down. The total loss is estimated to be up to a trillion RMB. The internet has become an indispensable part of economy. However, when the internet goes hand in hand with financial disorder, the systematic risk is worrying.

At the end of 2017, the total value of the assets of China's financial sector has amounted to RMB 250 trillion, topping the rest of the world.

Faced with the grey rhino of a looming global financial crisis, greater financial liberalization to deepen and accelerate financialization remained a major target of policy-making. Financial interest blocs have apparently taken a firm grip on China's policy decision making.

Worried by the trend, the top leadership warned on different occasions against the risk of disordered financial expansion. On June 2020, the State Council issued "Suggestions on Accelerating the Perfection of Socialist Market Economic System in the New Time," emphasizing the aim of finance being at service of the quality development of economy and society and the urgency of rectifying market disorder. At a summit on 24 October 2020, Wang Qishan, China's Vice-Chairman, reiterated the importance of finance to the service of the real economy and warned that the financial sector should not go astray with speculation and gambling, or even become a Ponzi scheme. Financial safety should be always prioritized over liquidity and profitability.

The Fourteenth Five-Years Plan as put forth in 2020 has set the goal of China becoming a "Strong Manufacturing Nation" and developing digital economy. How to reverse the crowding out of manufacturing by financialization in the last decade and ensure that finance would function as a humble servant of real economy would pose a great challenge. 


\section{The Lesson China Should Learn from the Crisis in the West}

The deepening of financialization and further opening up of domestic financial market had been a well-defined policy in China, which might have its reason considering the excess of financial capital. Amid the COVID-19 epidemic, China further opened its financial market on April 12020 as planned. At the time that this chapter was being written, it was not clear what its impact would be on Chinese economy. However, the global financial instability due to the epidemic outbreak should be considered as an alarm to this obsession with financialization. The western financial system should not be worshipped as an assumedly better institution. China should not simply copy the western capital market system which has been proven to be prone to instability, conducive for social inequality and bound for crisis. It would be irrational to simply duplicate a system that has such an increasingly poor track record.

Instead, China should look for new policy orientation and alternative path.

\section{Monetary Sovereignty}

As described in previous chapters, foreign exchange used to be a valuable resource for China as a developing country to repay foreign debts and stabilize its domestic currency. The state thus stipulated that all foreign exchange flowing into China had to be sold to the central bank. As China's foreign exchange reserve was expanding, so did its money base. As a consequence, the central bank money supply became exogenous. It led to the ineffectiveness of monetary policy as a tool of economic regulation. Hence, the restoration of an endogenous monetary mechanism became essential.

On 16 January 2019, an officer from the Treasury Department in the Ministry of Finance released the message of planning to link national bond issuance with the central bank's monetary policy operation. In other words, the state's credit would become the basis of monetary 
issuance, which is a common practice for many major economies in the world. For example, the total assets of the US Federal Reserve balance sheet in 2020 amounted to over $\$ 7.1$ trillion, mostly comprised of US treasury bonds, mortgage backed securities and institutional bonds. However, in comparison, China's central bank, as of July 2020, held foreign assets worth of RMB 21.8375 trillion in its balance sheet while merely RMB 1.5250 trillion of claims on Chinese central government. This striking structural imbalance could be viewed as a sign of incomplete monetary sovereignty upon which an economy could create money based on national credit to support its development.

If the RMB would no longer be pegged to the dollar and China's monetary mechanism would no longer rely on holding foreign assets, then the search for a new foundation of monetary value becomes imperative.

Moreover, confronted with the scenario of financial war imposed by the USA in which China might be forcibly delinked from the international US dollar system, seeking an alternative to the dollar in international settlement also becomes a pressing problem.

\section{A Race of Post Dollar Hegemony: Digital Currency and New Global Financial Order}

US global interest was sustained by dollar hegemony, a legacy of the Bretton Woods system and post Bretton Woods regime. The dollar was yet to be challenged as the global reserve currency and the default currency of international trade and settlement. As the value of money was backed almost solely by the creditability of the state behind it, the value of the dollar was secured by unchallenged US military dominance and the political and social stability of the USA. It remained the most preferred foreign exchange reserve many countries stock to stabilize their currencies. Because of it, the USA became the only nation on the planet able to prosper by perpetuating trade deficits and debt rollover.

The current international financial system was functioning only because of the dollar system. Without SWIFT and CHIPS (Clearing House Interbank Payments System), the global financial system would 
come to a halt. However, it virtually also afforded the USA the monopolized power of financial sanctions. Apart from direct military intervention, financial sanction through international clearing system became one of the most important and effective means to extend US global hegemony. Russia, Europe and quite a few countries were conceiving new alternative international clearing systems capable of bypassing the control of the USA.

With the rise of block-chain technology and cryptocurrency, it seemed that an alternative global currency and international settlement system eventually became conceivable and viable after more than 70 years of U.S. dollar hegemony. Nevertheless, decentralized cryptocurrencies like Bitcoin seem to be speculative fads boosted by the ideological fantasies of the Austrian School rather than practical tools to improve the economic well-being of people. Blockchain technology has yet to solve the trilemma of decentralization, creditability and cost. However, we should not underestimate the significance and impact of cryptocurrencies issued by big financial institutions or IT giants, which may pose a threat to sovereign currencies, especially of small economies. Furthermore, if the USA came up with a form of cryptodollar, then dollar hegemony might rise to a new level. It might mark the death of monetary and financial sovereignty of most of the countries in the world other than the USA.

It was against this backdrop that China prominently embraced the potentials of blockchain and cryptocurrency technology. As a leader in electronic payment, China, after six years of research for, launched in May 2020 a pilot scheme of DCEP(Digital Currency Electronic Payment) in four cities. It was a digital currency exclusively issued by the Chinese central bank. DCEP was supposed to be the replacement of M0 and pegged to RMB as legal tender generated and regulated by a centralized and exclusive model (being the only legal digital currency in China). However, it was more than a simple digitization of cash. In combination with big data, DCEP may improve the effectiveness of the central bank's monetary policies. As Huang Qifan, chairman of the China International Economic Exchange Center, put it in a speech at the China Finance 40 Forum, 
DCEP can achieve real-time collection of data related to money creation, bookkeeping, etc., providing useful reference for the provision of money and the implementation of monetary policies. $^{22}$

Apart from improving the efficiency of monetary policy and general transaction, its traceability may also help to monitor criminality.

Last but not least, whether being a pioneer in electronic payment and digital currency might facilitate to promote the RMB as a regional currency was still uncertain, especially against the backdrop of a growing hostile international geopolitical environment.

No doubt, the race for post-dollar hegemony was set on. How the global economic and financial regime was going to be reshaped was still unclear as of this chapter was written. However, a seismic change would be taking place. ${ }^{23}$

And at the domestic level, would the emergence of a digital currency improve the efficiency, transparency and creditability of industrial and financial chains and make finance really serve the real economy? Or would it open up a new round of speculative frenzy?

From the perspective of rural regeneration, we are more concerned with how to apply blockchain technology to the local community in building a local credit system. It may serve the development of rural endogenous cooperative finance. Unlike the "nobody trusts anybody" ideology, we are interested in how to localize blockchain technology and, hence, facilitate the cooperation and trust among rural communities and citizen-supported agriculture.

\section{The Astronomical Expansion of Debt}

The expansion of debt is always concomitant with financialization, as debt and finance are the two faces of the same coin.

At the end of 2000, the total balance of credit in China's financial system was RMB 9.9 trillion. By July 2014, it had grown to 78.02,

\footnotetext{
${ }^{22}$ https://boxmining.com/dcep/.

${ }^{23}$ See: Gustavo Moura, Paulo Natakani \& Erebus Wong, "Dollar Hegemony under Challenge and the Rise of Central Bank Digital Currencies (CBDC): a new form of world money?," in Wealth and Poverty in Contemporary Brazilian Capitalism. Palgrave Macmillan, 2021.
} 
an increase of $688 \%$ meanwhile the nominal GDP growth was merely $473 \%$. The expansion of credit was obviously greater than the growth in real economy.

According to the Institute of International Finance, China's total domestic debt as of the first season of 2020 amounted to $317 \%$ of GDP, the highest historical record (Fig. 1).

Top to Bottom: Financial sector debt, government debt, household debt, non financial corporations' debt.

In recent years, China has put much effort in deleveraging its economy. Nevertheless, while the growth of debts in other sectors has stabilized or declined, the growth of household debt has been striking. As of 2019, household debt has amounted to 54.3\% of GDP. Personal consumption based on debt is expanding. China is gradually shifting from traditional society with a high savings rate to a consumerist society based on debt.

Corporation debts have comprised the largest portion in the domestic debt stock. Since 2014 with the economic downturn, corporations have

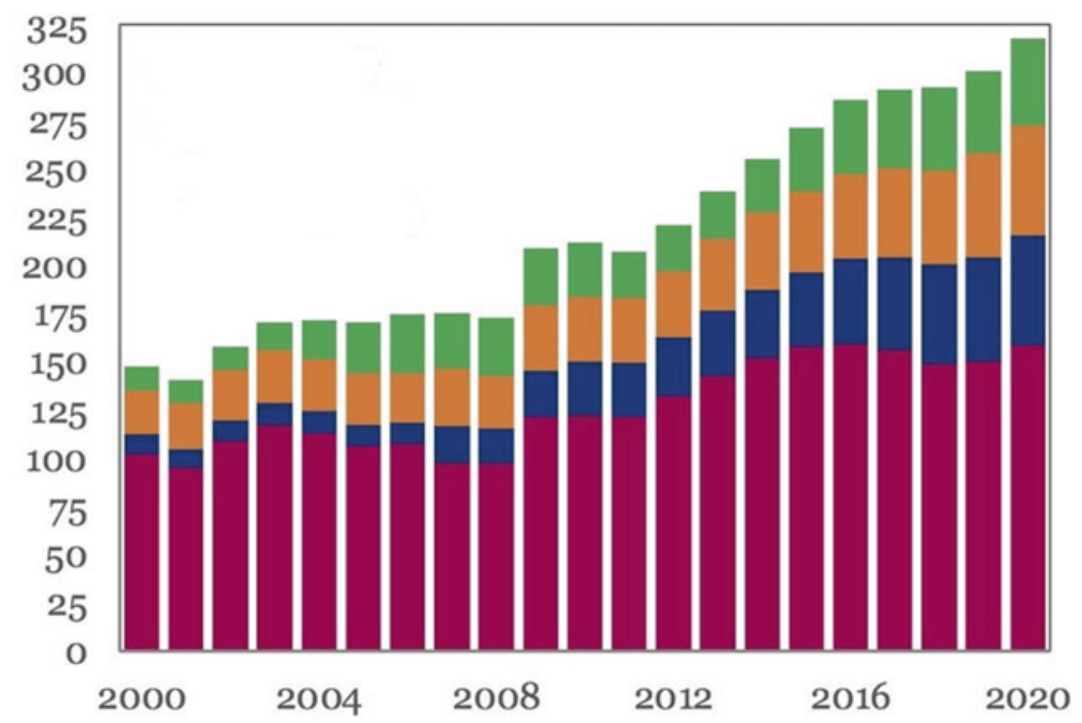

Fig. 1 Debt to GDP (\%) in China (as of March 2020) Original graph: MarginalLab 
found it increasingly difficult to fulfil their debt services. The numbers of bad default cases became obvious in 2019 ( $\$ 17$ billion in the first eleven months). ${ }^{24}$ It was expected that the covid-19 epidemic in 2020 would worsen the situation.

Local government debt is another issue of concern. Due to regional imbalance in economic development, only very few local governments have recorded fiscal surpluses. As of the end of 2019, the total local governmental debts were up to RMB 21.3 trillion, almost two times of general local budgets, not to mention many off-the-books and hidden debts. Many local governments maintain their functions and pay debt services by rolling over loans. China may need new monetary and fiscal mechanisms to tackle the problem of local government debts.

As of the end of 2019, China's foreign debts have amounted to $\$ 2.05$ trillion while it held $\$ 5.5$ trillion of foreign outstanding claims, of which over $\$ 1$ billion was US treasury bonds, which might never be repaid. The rest were mostly owed by developing countries, which became increasingly dubious in repayment as uncertainties in the global economy were mounting.

Of course, debt expansion is not exclusive to China. It is a global phenomenon under the financial capitalism regime. According to a report by the Institute of International Finance, as of March 2018, the total debt in the world (including governments, corporations, households and financial institutions) amounted to US\$ 247 trillion, a growth of $43 \%$ since 2008 while the GDP growth during the ten years after the crisis was only $37 \%$. Global debt/GDP expanded from 2.9 to 3.2. The new increase in private corporate debt was US\$ 28 trillion, two thirds of which was held by Chinese companies. China has functioned as the growth engine of the world. As the economy is slowing down, the burden of debt servicing may become troublesome.

Admittedly, a large part of debts in China is related with infrastructural construction. As long as the national economy keeps growing, they are productive debts. The truly worrying parts are non-productive debts such as mortgage and financial debt seeking virtual profits in speculation.

\footnotetext{
${ }^{24}$ It was still relatively mild considering the total $\$ 4.4$ trillion on-shore corporation bonds market.
} 
And we should not forget the mother of all debts, the US Federal Reserve Notes known as the dollar. Technically, the USA has been insolvent, especially after the new round of unlimited QE in 2020. The financial orgy goes on with perpetual debt rollover because the USA is still the greatest unchallenged political and military power in the world. The global economy has increasingly become a Ponzi scheme.

The expansion of debt is hanging over the world as well as China like the sword of Damocles. The USA's heavy indebtedness with endless roll-over and even repudiation can only be sustained by its unchallenged hegemony. In comparison, China can only rely on domestic debt expansion. Its mounting internal debt can only be sustained and guaranteed by a centralized system. Here lies the greatest mental confusion. Financial capital and its appendages have long claimed that Chinese institutions should be transited to the western model without acknowledging that western institutions are now built on the increasingly shaky ground of mounting indebtedness, which are not to be emulated by other countries.

\section{Land Issues: Land Finance and the Expansion of Real Estate Sector}

For China, land is not a generic issue. As elaborated in previous chapters, land had functioned as the key to resolve crises in different occasions. We may put it in this way: land is the foundation of the political regime in China.

However, since the tax revenues division reform in 1994 (see Chapter 3), many local governments have increasingly relied on landrelated revenues as the main source of general fiscal revenues. As seen in the following chart, of 30 major cities in China, over 26 were dependent on land finance (over $50 \%$ of fiscal revenues). 12 cities were heavily dependent (over 100\%).

Over-dependency on land finance led to problems such as enclosure of arable land, violation of peasants and citizens' right, inefficiency of land use and unreasonable expansion of urban areas etc. Furthermore, it also played a part in the creation of a real estate bubble (Fig. 2). 


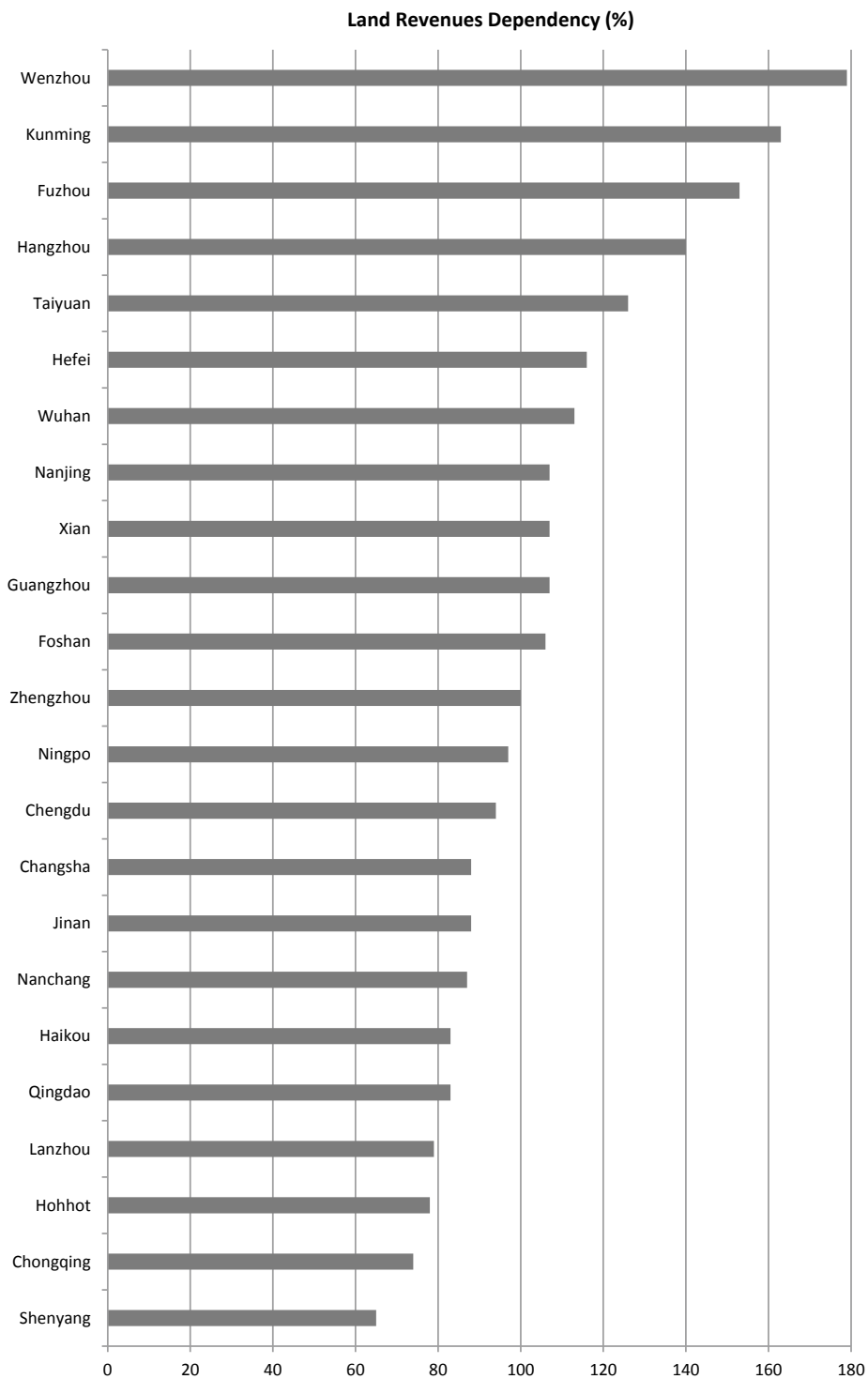

Fig. 2 Local governments land revenues dependency: land revenues/general fiscal revenues $X 100 \%$. Original chart: https://finance.sina.com.cn/china/gncj/ 2020-04-28/doc-iirczymi8742353.shtml. Chart: Land revenues dependency in 30 major Chinese cities, 2019 
Land Revenues Dependency (continued)

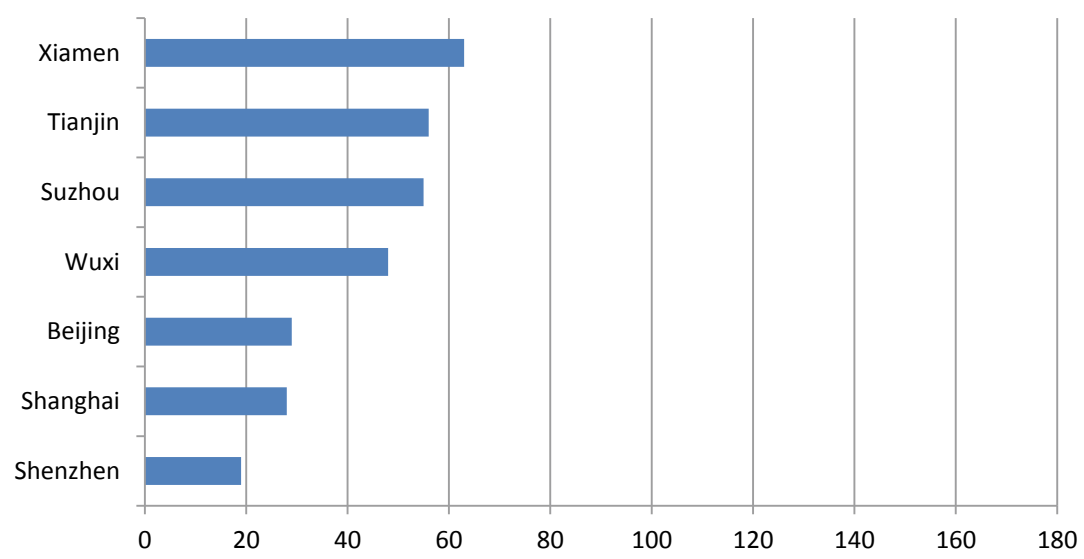

Fig. 2 (continued)

\section{Local Fiscal Budget Deficits}

Over dependence on land revenues is a consequence of long-term fiscal difficulties faced by local governments. Fiscal constraint had been a long-term problem for many local governments except some developed provinces and municipalities. ${ }^{25}$ The economic lockdown in the early 2020 further worsened the problem. The national fiscal revenues dropped by $21.4 \%$ and $26.1 \%$ in February and March 2020 year on year, the worst numbers since 2008 . The first season recorded a minus $14.3 \%$ in fiscal revenues growth, compared with 6\% last year. 2020 was the most difficult year for local fiscal budget since the tax division reform in 1994, not to mention the enormous expenditures on epidemic control (RMB 145.2 billion as of 19 April) and general relief (156 billion). The local budget deficits might reach $56 \%$ in the first season of 2020 .

The authorities responded by an expansion of local infrastructure projects bond, RMB 1160.7 billion as of 15 April with another 1000 billion before the end of May.

${ }^{25}$ Only 8 out of 31 provinces and municipalities recorded a revenues/expenditures ratio over $50 \%$ in 2019. See: 羅志恒 范城愷 “當前財政形募分析” (An Analysis of Current Fiscal Situation). 
To release local governments from over-relying on land revenues, it is pivotal to reform the taxation system which after all functions as the wealth-redistribution mechanism of a society. Land revenues are usually generated at the expense of transferring rural land resources to the urban sector. Inflationary land prices imply an implicit land tax on lower and middle classes as their costs of living and commerce are also being inflated. China's current taxation system mainly taxes individual income, goods trading (value-added tax) and services. Such a system in fact discourages involvement in the real economy and motivates people to speculate. It results in an unfair burden among classes. According to estimate, the richest class who own over $50 \%$ of the total wealth in China have contributed less than $10 \%$ of personal income tax while $60 \%$ are paid by wage earners. The current practice apparently fails to redistribute wealth among different classes in an equitable manner. A sensible taxation system should keep low tax rates on earned incomes from the real economy, including salary and profits of manufacturing and commerce. It should instead tax non-productive unearned income (rent-seeking) of the rentier class and capital gains, such as by property tax or assetsholding tax. Only through conversion of the current pro-speculation tax structure can China prevent its economy from hollowing and orient its society towards wealth redistribution in favour of the lower and middle classes.

\section{Real Estate: The Sisyphus Boulder of the National Economy}

Inflationary real estate price has caused a distortion in the Chinese economy.

According to a report by the National Bureau of Statistics, the total value of real estate in 70 major cities China amounted to US\$ 65 trillion in 2018, more than the sum of the value in the USA, EU and Japan as a whole. Meanwhile, the value of the Chinese stock markets was merely one tenth of the value of the above big three (Fig. 3).

There was an apparent distortion in Chinese citizens' wealth portfolio structure. According to a survey, the net value of housing property constituted $66.35 \%$ of Chinese household wealth in 2017 . It was 


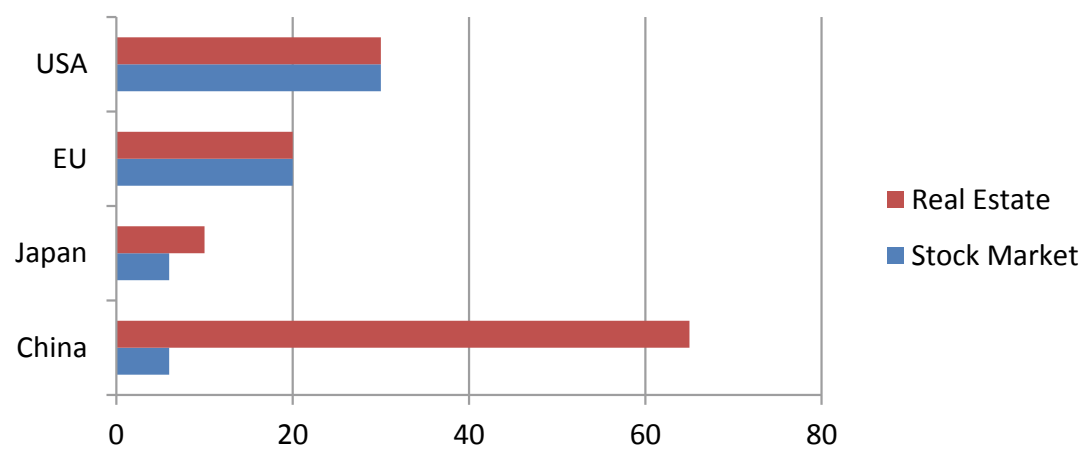

Fig. 3 Stock market and real estate total values 2018 (Unit: US\$ trillion)

a worrying trend. Mortgage expenses have sucked household dry of consumption power. The growth of citizen's disposable income lagged behind economic growth. Household savings even started to decline. It is contradictory to China's strategy to stimulate domestic demand as the main growth engine as the export-oriented and infrastructure structure investment-propelled models have exhausted their momentum. Real estate became an unbearable burden on Chinese society and economy. Chinese government got caught in a dilemma. On the one hand, the real estate bubble had to be restrained from growing further; on the other, crash in real estate prices would equally be a serious problem.

The authority expressed its concern. President Xi Jinping has emphasized in 2016 Central Economic Working Meeing the necessity of suppressing real estate bubble, emphasizing that "houses are meant for people's habitation, not for speculation". On the 19th National Congress of the CCP in 2017, he reiterated the principle again.

Last but not least, it is essential and also a challenge to maintain rural land collective ownership intact. As elaborated in previous chapters, collective land ownership can serve as a solid foundation for rural cooperative economy and self governance, which in turn are vital for rural social stability and eventually the stability of Chinese society as a whole. However, in the name of granting peasants full ownership, some policy researchers constantly suggest the privatization of rural land, which might destabilize the economy and eventually shake the foundation of the regime. 


\section{Structural Imbalance and Rebalance in Three Aspects}

Chinese economy and society has long been characterized by structural imbalance in three aspects: rural-urban divide, income/wealth gap and regional disparity in development. Balancing these three disparities has been the targets of the essential structural adjustment in the last phase of development.

Since the 1998 the central government has consistently been investing into rural development. The rural-urban divide is to a certain extant being narrowed while the rural income in general is rising. However, the gap is still obvious. Of the total population, 330 million enjoy GDP per capita of more than US\$25,000, while the other 1.05 billion have less than $\$ 4500$. The great divide is mostly drawn along the rural-urban disparity.

The income level of the nation as a whole has impressively multiplied in the last four decades. However, the wealth gap is also widening. In 2019, the average disposable annual income is about RMB 30,000. Meanwhile, 610 million people (including non-working persons) on average have a disposable monthly income of merely RMB 1000. Admittedly, a widening wealth disparity is a common phenomenon plaguing the whole world. The global capitalist regime is a highly effective wealthgenerating machine. However, it fails disgracefully manner when it comes to ensuring an equitable distribution of wealth, concentrating wealth into an exclusive elite bloc. Undoubtedly, China has successfully eradicated absolute poverty, one of greatest achievements in human history. Nevertheless, the sign of a widening wealth gap is indeed worrying whereas the aim of becoming a moderately well-off society has yet to be achieved in China.

\section{New Infrastructure Building and the Worry of Economic Polarization}

Amid the impact of the pandemic, Chinese government launched the New Infrastructure campaign, aspiring to regain economic momentum. 
The New Infrastructure was not a response to the crisis. Chinese government first proposed the New Infrastructure Building in December 2018, which was closely related to the "Made in China 2025" initiative. The crisis along with external pressure no doubt drove the country to add a larger stake on the game. "New Infrastructure" projects were focused in cutting-edge areas considered to be decisive in the coming industrial era: $5 \mathrm{G}$ networks, industrial internet, data centers, artificial intelligence, ultra-high voltage, and new energy vehicle charging stations. The investment was estimated to be worth about 100 billion yuan. These represented the nation's efforts to upgrade its economic structure when the old export-oriented model had come to an end.

Like the previous two crises, one of the aims of the New Infrastructure building was to create effective domestic demand to keep the economy growing. However, the New Infrastructure was different from the old infrastructure-driven model in an essential way. The new economy related with the new infrastructure was highly capital-intensive and generally labour-exclusive, especially the automation of production and service. Even if it could facilitate the creation of new economic model with new job creation, it does not appear that enough work opportunities might be created for those labours with lesser know-how and education. The new economy model, if not properly and carefully conducted, might further worsen the polarization of China's economic structure and national income and widen the above disparities which had long been troubling China.

\section{The Regional Mega Integration and the Dilemma of Regional Rebalance}

As for the third structural imbalance, regional rebalance has long been an important national strategy, as elaborated in previous chapters, with substantial investments into the western and northeast regions since the turn of century. The Belt \& Road Initiative has facilitated the relocation of industrial hubs toward the western part from coastal regions. However, as the international geo-political environment becomes increasingly 
hostile, uncertainty may be cast on the sustainable development of the western regions.

We also saw a spatial shift in China's regional disparity. During the last ten years, north-south disparity has replaced east-west (coastalhinterland) gap as the main feature of regional disparity. In 2009, the greater northern regions accounted for $43 \%$ of the total GDP. However it has dropped to $35 \%$ in $2019 .{ }^{26}$ In 2009 , the northern regional GDP was $176 \%$ of the southwest which were traditionally the poorest regions in China. However, the situation was reversed in 2019 when the former's GDP accounted for merely $84 \%$ of the latter's.

Furthermore, this disparity is likely to be consolidated as the state pushes forth in recent years regional integration in Yangtze River Delta Zone, Guangdong-Hong Kong-Macao Greater Bay Area and BeijingTianjin-Hebei region as the most essential national strategy meanwhile we see so far no major strategic development plan for the northeast. The strategy should be understood against the changing international background in which the trend of reverse globalization, the rise of unilateralism and protectionism and the uncertainty in an increasingly hostile geopolitical environment have posed serious challenges for China. Four decades of China's participation into globalization has come to a turning point. It may be reasonable to focus resources on advanced regions which already hold the advantage. Nevertheless, the decades-long aim of structural rebalance would be confronted with even greater challenge.

\section{Dual Circulation Strategy}

The Chinese leadership has proposed in 2020 the new strategy of Dual Circulation, facing enduring weak demand in global market after the ending of QEIII in 2013, rising protectionism and uncertainty in geopolitical surrounding, mainly arising from increasing antagonism by the USA and its allies. Domestic demand is once again staged as the mainstay after 30 years of relying on international trade as the main growth engine. In fact, the weight of export in GDP has declined from $35.4 \%$ in 2006 to

26https://www.huxiu.com/article/341548.html. 
$17.4 \%$ in 2019 . In other words, domestic demand has already accounted for $82.6 \%$ of the GDP. The strategic adjustment reflects a natural transition in the trend of the tapering of the export-oriented sector. In fact, the authority has given up setting a rigid GDP growth target and instead aims at quality rather than quantitative growth.

However, the Chinese authorities have stressed that it does not imply a closed and isolated domestic market. International cycle (trade) will continue to function as an indispensable supplement to the domestic cycle. Given the massive volume of its economy, China's domestic market would continue to be a major epicentre of global supply chains. The Chinese authorities therefore emphasizes that it will keep its market open to foreign investment. In fact, a significant change in recent years has not only been in the export of manufactured goods but also in industrial standards, such as high speed railway system and $5 \mathrm{G}$ technology. If the current trend of US-China decoupling goes on and even escalates, the global economy may diverge into two or several major supply chains networks, each with its own industrial standards.

Needless to say, the key to the feasibility of the Dual Circulation Strategy is how to develop a healthy and balanced domestic market. It is highly correlated with many of the major problems we have discussed as above. How to boost domestic demand by raising national income level in general? On the one hand, how to raise the 1 billion rural and urban lower class with less than $\$ 4500$ GDP per capita to a level closer to their 330 million fellow countrymen and women? How to achieve rebalancing in the three aspects, namely the rural-urban divide, wealth gap and regional disparity? How to avoid the widening of regional disparity while concentrating resources in the three leading regional mega zones? On the other hand, how to avoid the consumption power of urban middle-class being increasingly depleted by expenditures in housing and mortgage? How to reform the taxation system to release consumption power? These challenge would require a thorough modification of the economic system.

Of course, the prerequisite of the viability of the Dual Circulation strategy is that the two basically antagonistic international supply chains systems find a way to co-exist in a competitive but relatively peaceful manner without eventually ending up with fatal confrontation. 


\section{Ecological Civilization: Localization as Alternative to Globalization}

\section{Policy Adjustment: Rural Revitalization}

China is facing a multi-dimensional crisis with exogenous and endogenous factors. How to deal with the problem of deindustrialization as capital moves into the speculative sector seeking higher profitability? How to prevent deindustrialization from leading to large scale unemployment? How to avoid systematic financial crisis? How to secure the survival of small and medium enterprises and improve their competitiveness? How to convert the over dependency on international trading by promoting domestic demand? How to prevent consumption from being squeezed by real estate and finance at the national level? How to prevent the intensification of class struggle (labour-capital conflict) under such a crisis? The key is to let the majority of the citizens share the fruit of growth in a more equitable way. It requires containing various interest blocs within the polity. Decades of developmentalism has brought about severe ecological degeneration, income disparity, class tensions and moral hazard behaviour. China has to deal with a highly complicated relationship: domestically and internationally, between central and local governments, between finance and the real economy, between the state and society etc.

Since 2017 the government has adjusted its policy by returning to counter-cyclical measures through creating effective demand. Another important policy is to foster an eco-friendly economy as an alternative development strategy. Hence the slogan, "green mountain is gold mountain; clean river is silver river". One of the major strategies of rural vitalization is the valuation of natural resources in villages as well as the "capital-deepening of eco-economy" as ways to resolve the crisis of excess money-supply caused by the trade surplus and the inflow of foreign capital.

In a word, the current moves on the economic front constitute China's proactive effort to steer away from decades of developmentalism in line with the western model of modernization. "Beautiful villages" are conceived to be the carrier of "beautiful China". The national 
development strategy is gradually adjusted toward inclusive sustainable development which is resource-efficient and eco-friendly. Ecological civilization, rural vitalization, and poverty eradication are among the essential strategies of transformation.

\section{COVID-19 Epidemic as a Strategic Time Window}

Although the epidemic was unexpected its impact was in fact not a surprise. This historical juncture of US hostility along with an epidemic outbreak urged people to have a timely and profound reflection on the old development model of over-relying on export-oriented economy, a rough extensive growth model which focused on quantity rather than quality, with risk accumulating. The guiding strategy should not be the "back to business as usual" mindset attempting to sustain the old model and put patches on the fractured global industrial chain. Nearly four decades of practices have proven that the export-oriented model was actually a prolonged overdraft on the eco-system and social reproduction. The price of overdraft would inevitably turn into social conflicts. China should take this chance to really steer the economy and society as a whole toward ecological civilization with the ecologization of industry. Then this crisis would become a chance.

\section{Rural Society as the Condition of Crisis Soft Landing}

The urban economy that is comprised of concentrated profit-seeking capital is characterized by risk. In comparison, rural society is based on household and community cooperation, which is an effective means to internalize negative externalities. Whereas the urban economy is driven by economic rationality which often leads to irrational behaviour, the rural community is maintained by what can be considered cooperative rationality. We have proposed that for decades Chinese rural society has served as the buffer to absorb negative externalities generated by the urban economy and as the vehicle for soft-landings to crises. However, in recent years, the foundation of rural society's capability to absorb negative externalities has been eroded. This is due to several reasons. For 
decades, production factors (labour, capital, land etc.) have been draining out of rural communities. Peasants have become disorganized, therefore rural governance has deteriorated. The rural household economy has become underdeveloped compared with the capital-intensive urban economy.

Developing the cooperative economy is the key to rebuilding a robust rural society, which may once again serve as an antidote to the risk-based and risk-accumulating urban economy. Based on principles and practices of a cooperative economy, peasants can organize themselves, which in turn can consolidate the foundation of rural governance. The localized capitalization of rural resources based on cooperatives may help to shape a strong and healthy domestic demand.

\section{The Valuation of Rural Ecological Resource and Cultural Assets}

After a few years of fruitless policy, the central government proposed the strategy of rural vitalization in 2017. The government has adjusted its agrarian policies, which amount to:

1. A diversion from the policy of accelerating urbanization in recent years. Instead it has begun to emphasize the priority of agriculture and the rural.

2. An assertion that rural vitalization is the most creative aspect of China's development in the twenty-first century.

3. An abandonment of the path dependence of quantitative growth and a turn towards eco-friendly (quality) growth and development.

Despite the limited nature of present discourses, the policy-makers have turned their perspective to rural China and once again emphasized the importance of the rural sector. Can it save China again as it did in previous crises? Facing the current crisis, we should remain cautiously optimistic. 


\section{New Infrastructure Building Should Steer Toward the Sannong}

The post-pandemic investment into New Infrastructure should not be a simple expansion on the old infrastructure. Neither should it be over concentrated on the urban sector. The fiscal and financial policy should be favourable to the sannong as a way to revitalize the rural sector. The valuation of rural ecological resources and cultural assets based on village collective and cooperative economy could serve to enlarge the national real assets pool. Then China's money supply would no longer have to rely on foreign exchange reserves. Instead, the value of Chinese currency should be pegged against the monetarization of national resources. The reconstitution of monetary sovereignty could lay a solid foundation for financial risk management. So-doing would safeguard the national economy against the probable impact of increasingly serious global financial crisis in a world market flooded with unlimited quantitative policies by advanced countries.

China's current M2/GDP is up to $200 \%$, among the highest level in the world. However, we should not simply conclude from this that Chinese economy is shaky due to money oversupply. Compared with other advanced economies, China is characterized by a feature: many assets in rural regions have not yet been valued and priced, or their value remains implicit. Capital in the urban sectors is currently in excess and seeking the opportunity for the capitalization of resources. For this reason, the trend of capital flowing into the rural sector seems to be irreversible. Viewed another way, it may be a chance to reverse the decadeslong draining of production factors (labour, capital and land) from the rural sector. The problem becomes how to avoid malicious and destructive enclosure of rural resources by capital and finance. The formation of cooperatives becomes a key element in this process. Supported by the national strategy of ecological civilization and rural vitalization, rural community cooperatives can become effective agents in the valuation of ecological and cultural assets. Through appropriate institutional innovations, a part of the property rights can become exchangeable assets on a well-designed special market, while the fundamental ownership of vital resources like land remains with the community cooperative. This may 
attract capital flowing into the rural sector in a healthy and constructive way. Factors like labour, capital, technology and land may contribute to localized rural vitalization. The fiscal pressure of eco-infrastructure and rural construction can be partly relieved through this form of financing at the same time that excess liquidity in the urban sector can be channelled into the rural sector. This can promote peasant income growth while preventing the formation of financial bubbles in the national economy. Income increment can serve as a foundation for economic reproduction, the provision of public services for rural communities, the protection of ecology and the improvement of rural governance.

To achieve this, the state must stick to the principle of inclusive finance. The central government must make good use of its monopolized financial sector to establish financial mechanisms below county level to serve the new rural reconstruction. Finance must not only seek the maximization of profits. State-run finance especially has to fulfil its policy-oriented functions to stabilize rural society, create job opportunities in rural regions and promote community welfare.

As long as institutional arrangements and innovation are appropriate, the valuation of implicit cultural and ecological assets can easily absorb the money stock which, otherwise, will turn into excessive liquidity leading to financial bubbles.

\section{From Globalization to Localization: Rural Vitalization}

In the post-globalization world, China is facing both industrial overcapacity and capital oversupply. Chinese political and economic elites therefore feel compelled to expand their presence in the world. However, the world has changed. After decades of globalization and neoliberalism, worldwide social reactions (Polanyi's double movement) have raised vociferous and strong protest against their progress. Ecological degeneration and climate catastrophe have signalled the limit of the prevalent growth model. Even if these Chinese elites emphasize that China is merely seeking equal and bilateral cooperation for development opportunity, the unipolar power, which has remained unchallenged for nearly 30 years and indulging in the ingrained Thucydides trap, naturally regards 
it as a challenge to its hegemony. Every move by a big country like China will be taken as a transgression against the presence of the dominant geopolitical power. Advancing with an expansionist strategy in the post globalization age, China has to face vicious competition and even a new cold war. Admittedly, the alternative option is not isolationism or autarky. However, an indispensible and more intelligent strategy would be to re-emphasize domestic economic circulation by ameliorating the gap between the urban and the rural, the rich and the poor, different regions, and different sectors. The external circulation (international trade) would serve as a complement to the internal one.

If China persists with the strategy of rural vitalization, determined to pursue the path of ecological civilization, its heretofore capacity to deal with global crises might still remain intact.

\section{Conclusion: Ecological Civilization as New Paradigm for Developing Countries}

The once-shining so called 'emerging economies' (so dubbed ideologically) are still struggling to keep their footing after the post-2008 shock. Except for China which is still not recognized as full market economy, most of them are plagued to a certain extent by industrial degeneration. Some have even retrograded to pre-modern mode of resources export.

Most of the developing countries in the last 100 years have been pursuing modernization according to the western model and pushing developmentalism. However, at the end of the day, many of them found themselves ensnarled in the development trap. The reason may be attributed to the irreplicability of the western development path: colonization. (On the side of the West, it becomes a sort of path dependence.)

China is a late developing, populous 'continental economy'. Colonization was never an option. Hence it went through a path different from the West. By the extraction of surplus from the sannong as evaluated in previous chapters, China accomplished the primitive accumulation needed for industrialization and the subsequent expansion. However, China has to convert to an inclusive growth oriented towards ecological 
civilization if it wants to sustain development in the 'race to the bottom' global competition plagued by the cost transfer of financial capitalism.

\section{The Institutional Experience of China's Late-Developing Introvert Industrialization}

Unlike the West which developed by colonial plundering overseas during the fifteenth to early twentieth centuries and then transferred the cost of economic upgrading through global regime after the WWII, China achieved industrialization through introvert primitive accumulation in two ways: (1) extracting the surplus value of labours of the whole nation through highly collectivized social organization and the agricultural surplus through the price scissors between industrial and agricultural products; (2) investment of large-scale labour force into state infrastructure building. In the second, labour force resource was capitalized as a substitute for capital scarcity. This whole nation mobilization system afforded China with the capacity to accomplish the 'alarmingly dangerous saltation' of primitive accumulation for industrialization without compromising national sovereignty. However, the enormous institutional cost of this untypical development growth had to be carried by all citizens (and often unevenly).

The government corporatism with Chinese characteristics that took shape in the above process became 'path dependence' in later institutional transitions. Out of responses to crises known as reforms, a 'governmentcorporate market economy' emerged. This centralized system is much criticized for its monopoly by the state-run sector. Nevertheless, one should not neglect the fact that China manages to sustain a relatively complete and intact industrial structure because of this government corporatism.

From an institutional-cultural point of view, two effective mechanisms took shape in China's modern state-building. First, it made use of the historical legacy of collective and cooperative culture to dissolve the serious externalities of market economy through internalizing the cost into community cooperation. Second, rural households dealt with the 
problem of capital scarcity by a non-monetized 'intensive labour investment portfolio' intrinsic to the millennial-year old peasant economy. We believe these two mechanisms helped China to accomplish industrialization not achievable by many third world developing countries emulating western institutions.

\section{Ecological Civilization and Sustainable Inclusive Growth}

Rural society as the carrier of soft-landing in various crises has experienced fundamental changes in the last two decades. Large scale migration of young labour force out of villages renders the rural an aged society. Most of the capital gains of rural labour force are taken by internal and external capital as well as developed regions. Collective culture as the foundation of rural society is disintegrating. As a result, the basic condition of 'risk-internalizing mechanism' (sustaining gains through self capitalization of household labour force and resources) based on peasant household rationality ${ }^{27}$ is also diminishing.

After 20 years of one-sided pro-capital mentality, the Chinese leadership switched to a pro-people well being policy orientation after 2003 . New Rural Reconstruction was put forward in 2005 as national strategy. Then the idea of Ecological Civilization was introduced in 2007. A year later, the goal of building a 'resource-conserving and environmentfriendly agriculture' was set up. Since 2005, over 8 trillion yuan (about US\$ 1.2 trillion) has been invested into rural development. Such a scale of infrastructure investment into rural regions regardless of short-term returns is unprecedented in the world including developed countries. The effect is quite remarkable. Most of the villages in China now have access to paved roads, piped water, electricity, communication and broadband internet. The business cost of rural small and medium enterprises is significantly reduced. Diversified non-agricultural economy is spared

\footnotetext{
${ }^{27}$ Peasant household rationality as a sort of cooperative rationality is contrast to individualistic rationality emphasized by modern economics. It is non-individualistic cooperation for the sake of the benefit of the whole.
} 
with the room to develop in villages, attracting labourers moving back to rural regions.

Nevertheless, local governments, by path dependence of government corporatism, cling to the developmentalist 'high investment-high debt-high GDP' model. Rural regions are still confronted with the problem of resource drainage and ecological unsustainability. The crux lies at whether it is possible to create an institutional condition to faithfully implement the strategic adjustments by the central government.

To build an ecological civilization, the first step is to abandon the GDP-supremacy mentality. Economy must be re-embedded into society and society into ecology. The idea of ecological civilization is a response to the social and cultural crisis of post industrial civilization. It calls forth a paradigm change in civilization. After all, the development of civilization is ultimately over-determined by ecology. The idea must question the development of capitalism in the last five centuries. It is high time we ponder upon our relationship with the nature, with society, with others, with ourselves, which are being shaped by capitalism (and worse still financial capitalism). If our existence is embedded into ecology, then we must hold nature in awe and constantly remind ourselves that nature is an end in itself rather than a means to other purposes, such as economic growth.

China is one of the very few civilizations that have evolved without break for a few thousand years. Its struggle to achieve modernization in the last 150 years is a tragic and heroic saga, a part of which this book attempts to illuminate. After all the pains and efforts, the revelation of the lesson is the idea of ecological civilization which questions morbid modernization we are still entrapped in. China's experiences in the last 70 years may be valuable not only to developing countries but also to the whole world. 
Open Access This chapter is licensed under the terms of the Creative Commons Attribution-NonCommercial-NoDerivatives 4.0 International License (http://creativecommons.org/licenses/by-nc-nd/4.0/), which permits any noncommercial use, sharing, distribution and reproduction in any medium or format, as long as you give appropriate credit to the original author(s) and the source, provide a link to the Creative Commons license and indicate if you modified the licensed material. You do not have permission under this license to share adapted material derived from this chapter or parts of it.

The images or other third party material in this chapter are included in the chapter's Creative Commons license, unless indicated otherwise in a credit line to the material. If material is not included in the chapter's Creative Commons license and your intended use is not permitted by statutory regulation or exceeds the permitted use, you will need to obtain permission directly from the copyright holder.

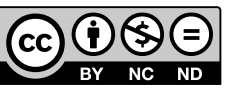

